African Journal of Educational Studies in Mathematics and Sciences Vol. 16, No. 1. 2020

\title{
GeoGebra integration and effectiveness in the teaching and learning of mathematics in secondary schools: A review of literature
}

\author{
Marie Sagesse Uwurukundo ${ }^{1}$, Jean François Maniraho ${ }^{2} \&$ Michael Tusiime $^{3}$
}

\begin{abstract}
This article explores studies that investigated GeoGebra integration and its effectiveness in teaching and learning mathematics. The study examines existing studies on how and why GeoGebra enhanced students' performance; understanding, analytical thinking, generalization, abstract thinking, representation, and logical thinking. By a deep exploration of the main construct of the study, we collected and analyzed 20 studies whose results reported that GeoGebra added values when applied in teaching and learning in different mathematical domains. The reviewed literature identified four domains in Mathematics: Geometry, Algebra, Calculus, and Trigonometry that was studied. The majority of the reviewed studies investigated the integration of GeoGebra in Geometry and few studies were found in other mathematical domains. The literature ascertains that students can explore independently the software and acquire mathematical concepts with minimum assistance from the teacher. The results from the reviewed literature, on the one hand, indicated $16 / 20$ or $(80 \%)$ of the studies generally showed that GeoGebra is effective in teaching and learning Mathematics since GeoGebra contributed in enhancing students' understanding of mathematical concepts and improved students' interest to learn mathematics. On the other hand, only $4 / 20$ studies or $(20 \%)$ showed non-effectiveness of GeoGebra since students in both experimental and control groups did not show the difference in their performance after being both given post-tests or an interview. This may indicate that although GeoGebra seems to be largely effective, such effectiveness is dependent on the way it is integrated into the teaching and learning process. Therefore, we recommend that other research should step up investigating why most of the studies were found in the Geometry domain and few in other domains.
\end{abstract}

Keywords: GeoGebra integration, GeoGebra effectiveness, mathematical domains, teaching and learning mathematics, attitudes towards GeoGebra

\section{Introduction}

In the most recent decades, the world has experienced rapid growth of technology which involves the introduction and design of educational software (Singh, 2018). As such, different studies have been conducted on technology-assisted teaching and learning, whereby different factors have been identified for the successful integration of such technology (Reis \& Ozdemir, 2010; Akkaya, Tatar, \& Kağizmanli, 2011; Gómez-Chacón, 2011). GeoGebra is one of the educational software which has been designed and investigated by some studies as to what extent its use enhances students' conceptual understanding and attitudes towards mathematics (Thambi \& Eu, 2013; Tran, Nguyen, Bui, \& Phan, 2014; Adegoke, 2016). The potentials of GeoGebra as an ICT tool on students' mathematical thinking improvement was investigated and found that GeoGebra is effective as long as it is integrated effectively into teaching mathematics in all levels of education, from primary education (Bulut et al., 2016) up to

\footnotetext{
${ }^{1}$ Marie Sagesse Uwurukundo is a Doctoral student at the African Centre of Excellence for Innovative Teaching and Learning Mathematics and Science, University of Rwanda - College of Education. sagesseuwurukundo@gmail.com

2 \& 3Jean François Maniraho \& Michael Tusiime, are academics at University of Rwanda College of Education, Rwanda.

Open Access article distributed under the terms of the Creative Commons Attributions License [CC BY-NC-ND 4.0] http://creativecommons.org/licenses/by-nc-nd/4.0. DOI: https://dx.doi.org/10.4314/ajesms.v16i1.1
} 
GeoGebra Integration and Effectiveness in the Teaching and Learning of Mathematics in Secondary Schools: A Review of Literature

M. S. Uwurukundo, J. F. Maniraho \& M. Tusiime Rwibasira postgraduate studies (Aydos, 2015). Akanmu, Isaiah, and Adegoke (2016) argued that there is a need for incorporating GeoGebra as an ICT tool and dynamic software in teaching and

learning mathematics. Besides, GeoGebra integration in teaching-learning mathematics contributes to the arousal of students' achievement and interest ( Jusufi \& Kitanov, 2019; Wassie \& Zergaw, 2019).

GeoGebra is a mathematical software package used in the teaching of different topics in Mathematics, for instance, Geometry, Calculus, and Algebra separately. GeoGebra software integration as a tool in the teaching of Geometry leads to the attainment of better students' grades, students' conceptual understanding of mathematics, and teachers' professional development (Mainali \& Key, 2008; Ibrahim \& 1lyas, 2016, Jelatu, Sariyasa \& Ardana 2018). In the studies conducted by Seloraji and Eu (2017), Jelatu, Sariyasa, and Ardana (2018), and Singh (2018) showed that GeoGebra integration in Geometry enhanced students' performance. The authors confirmed that using GeoGebra in teaching and learning geometry provides students opportunities to explore in detail the concepts and helps students to develop their knowledge in Geometry. Furthermore, Ibrahim and Ilyas (2016) found that the use of GeoGebra is an alternative way of teaching Trigonometry, especially when teaching the periodicity of trigonometric functions. The authors found that GeoGebra assisted Mathematics instructions to be more effective than teaching with traditional methods which are dominated by expositive mathematical instruction. Likewise, Mudaly and Fletcher (2019) observed while teaching linear algebra that, the integration of GeoGebra helped learners to successfully recognize properties of the straight line graphs. The purpose of this study is to investigate how GeoGebra was integrated and why it was reported to be effective in enhancing students' performance in Mathematics.

\section{Literature review}

\section{GeoGebra Integration in Teaching and Learning Mathematics}

Studies have been conducted on Teachers' Technological Pedagogical Content Knowledge (TPACK) issues (Kirikçilar \& Yildiz, 2018; Lancaster \& Bain, 2019; Njiku, Mutarutinya, \& Maniraho, 2020). With continuous updates and innovations for teaching mathematics with the new version of GeoGebra dynamic mathematics software (Baltachi \& Yildiz, 2015), mastering GeoGebra software is not enough, instead, GeoGebra is in need to meet teaching goals (Andresen \& Misfeldt, 2010). That is why Verhoef, Coenders, Pieters, van Smaalen, and Tall (2015) in their studies said that teachers designed a lesson in a way that helped students to understand derivative using GeoGebra as a tool. By establishing a reliable training platform, teachers in Nepal became confident in attempting to use GeoGebra in their teaching (Mainali $\&$ Key, 2012). Furthermore, Taiwanese teachers have mostly used related GeoGebra exercises found in textbooks, specifically to visualize textbook examples ( $\mathrm{Lu}, 2009$ ). With the introduction of new technology and new pedagogy to solve new problems, the teachers' potentialities and abilities to teach mathematics are deepened (Haciomeroglu et al., 2009).

\section{Teacher's Attitude towards the use of GeoGebra}

The preliminary quality of a teacher in integrating technology in teaching is the teacher's personality. This involves the teacher's knowledge and commitment to improving his/her teaching to make learners love mathematics (Žilinskienè \& Demirbilek, 2015). The study conducted by Doruk, Aktümen, and Aytekin (2013) showed that pre-service teachers took GeoGebra to be a powerful tool in mathematics education. The participants also reported that apart from having instructional advantages, GeoGebra has also effective benefits by increasing 
interest in mathematics instruction and making students like mathematics. Contrarily, the study conducted by Mainali and Key (2012) on mathematics teachers in Nepal, showed that though teachers had a positive impression and were motivated to know more about GeoGebra, they were not willingly prepared to integrate it in their teaching of mathematics subject.

Prospective teachers reported that developing and teaching a lesson with GeoGebra use influenced positively their views about teaching and learning Mathematics and enhanced their lesson delivery in various areas of Mathematics in secondary schools (Haciomeroglu et al., 2009). However, pre-service teachers in Ghana argued that one of the barriers they met is the lack of awareness about GeoGebra and the insufficient time in preparing lessons that involve the use of GeoGebra (Escuder \& Furner, 2011). As Saralar, \& Ainsworth, (2017) concluded, regardless of the challenges faced by middle school mathematics teachers in using GeoGebra, teachers still have positive attitudes towards the use of GeoGebra, and they are ready to continue using it in the future.

\section{The effectiveness of integrating GeoGebra in the teaching and learning of Mathematics}

The effects of GeoGebra as a crucial educational resource, a properly designed corresponding curriculum that ensures technology integration in lessons, exploring GeoGebra's inputs and added values in enhancing students' high achievement and attitudes, are areas that need more attention and researches (Wassie \& Zergaw, 2019). The study conducted by Dikovic (2009) showed that GeoGebra integration allows students exploration of function types and provides them to make the connections between symbolic and visual representations. The students' perception of GeoGebra in the learning of circles studied by Shadaan and Eu (2013) showed that through GeoGebra integration, the students improved their level of thinking, creatively and critically and they can make logical assumptions. GeoGebra developed visualization and understanding in different mathematical topics, an example of Geometry (Akkaya, Tatar, \& Kağizmanli, 2011; Thambi \& Eu, 2013). According to Chimuka (2017), the effect of integrating GeoGebra in the teaching of circle increased the focus of the students in mathematical concepts and also reduced the effort that can be made in computations. For the study conducted by Kim and Md-ali (2017) and Azizul and Din (2016), it was found that students were interested to learn mathematics because of the opportunity to use the GeoGebra while learning and the opportunity got of interacting with peers. Authors reported that this dynamic software enabled students to think and to make connections between concepts in shape and space and provided students with a link to their everyday life practices.

\section{Methodology}

We conducted a literature search to collect data related to GeoGebra integration and its effectiveness in the learning of Mathematics in secondary schools. The search was done by the first author by searching and downloading article papers on Google Scholar database. By using 'GeoGebra, GeoGebra integration, GeoGebra to teach and learn Mathematics, the effect of GeoGebra in teaching, the effectiveness of GeoGebra in teaching and learning Mathematics, and GeoGebra integration in teaching Mathematics' as search keywords, 56 studies were obtained. In which, 23 studies that were not related to GeoGebra integration and effectiveness in teaching and learning mathematics were filtered out. We remained with 33 studies, in which we further filtered studies related to teacher's knowledge about GeoGebra to teach Mathematics, and studies related to teacher's attitude towards GeoGebra's effectiveness in teaching Mathematics. As we considered the construct of the study (Lavrakas, 2008), we remained with 20 studies that describe GeoGebra's integration and its effectiveness in teaching and learning mathematics. These studies were published between 2010 and 2019. The reviewed studies are presented in Table 1 showing four existing mathematical domains in secondary 
GeoGebra Integration and Effectiveness in the Teaching and Learning of Mathematics in Secondary Schools: A Review of Literature

M. S. Uwurukundo, J. F. Maniraho \& M. Tusiime Rwibasira schools, commonly known as Calculus, Geometry, Trigonometry and Algebra that were discussed.

Table 1 GeoGebra integration in teaching and learning Mathematics

\begin{tabular}{|c|c|c|c|c|c|c|}
\hline $\mathrm{SN}$ & Author & $\begin{array}{l}\text { Domain of } \\
\text { Mathematics }\end{array}$ & Topics & Sample & Variables & $\begin{array}{l}\text { Statistical } \\
\text { significance }\end{array}$ \\
\hline 1 & Singh (2018) & Geometry & $\begin{array}{l}\text { Euclidian } \\
\text { Geometry }\end{array}$ & $\begin{array}{l}\text { Students } \\
(45)\end{array}$ & $\begin{array}{l}\text { Lines, angles } \\
\text { and triangle }\end{array}$ & - \\
\hline 2 & $\begin{array}{l}\text { Jelatu, } \\
\text { Sariyasa, and } \\
\text { Ardana (2018) }\end{array}$ & Geometry & $\begin{array}{l}\text { Geometry } \\
\text { concepts }\end{array}$ & $\begin{array}{l}\text { Students } \\
(60)\end{array}$ & $\begin{array}{l}\text { Geometrical } \\
\text { concept and } \\
\text { spatial ability }\end{array}$ & - \\
\hline 3 & $\begin{array}{l}\text { Jelatu, } \\
\text { Sariyasa, and } \\
\text { Ardana } \\
(2018)^{*}\end{array}$ & Geometry & $\begin{array}{l}\text { Geometry } \\
\text { concepts }\end{array}$ & $\begin{array}{l}\text { Students } \\
(60)\end{array}$ & $\begin{array}{l}\text { Spatial ability } \\
\text { for students to } \\
\text { understand } \\
\text { geometric } \\
\text { concepts. }\end{array}$ & - \\
\hline 4 & $\begin{array}{l}\text { Seloraji and Eu } \\
(2017)\end{array}$ & Geometry & $\begin{array}{l}\text { Geometrica } \\
1 \text { reflection }\end{array}$ & $\begin{array}{l}\text { Students } \\
(24)\end{array}$ & $\begin{array}{l}\text { Geometrical } \\
\text { studies }\end{array}$ & $\begin{array}{l}\text { ANOVA } \\
\text { with } p<.05\end{array}$ \\
\hline 5 & $\begin{array}{l}\text { Saha et al. } \\
(2010)\end{array}$ & Geometry & $\begin{array}{l}\text { Learning } \\
\text { coordinate } \\
\text { geometry }\end{array}$ & $\begin{array}{l}\text { Students } \\
(53)\end{array}$ & - & $\mathrm{p}=.036<0.5$ \\
\hline 6 & $\begin{array}{l}\text { Shadaan and } \\
\mathrm{Eu}(2013)\end{array}$ & Geometry & $\begin{array}{l}\text { Learning } \\
\text { circles }\end{array}$ & $\begin{array}{l}\text { Students } \\
(53)\end{array}$ & Circles & - \\
\hline 7 & $\begin{array}{l}\text { Masri et al. } \\
(2016)^{*}\end{array}$ & Geometry & $\begin{array}{l}\text { Learning of } \\
\text { Circles }\end{array}$ & - & - & - \\
\hline 8 & $\begin{array}{l}\text { Khalil, Farooq, } \\
\text { Çakiroglu, } \\
\text { Khalil, and } \\
\text { Khan (2018) }\end{array}$ & Geometry & $\begin{array}{l}\text { Analytic } \\
\text { geometry }\end{array}$ & $\begin{array}{l}\text { Students } \\
(40)\end{array}$ & - & $\begin{array}{l}\mathrm{t}=2.6 \text { and } \mathrm{p}- \\
\text { value }=0.012 \\
<0.05\end{array}$ \\
\hline 9 & Khalil ( 2017) & Geometry & $\begin{array}{l}\text { Analytic } \\
\text { geometry }\end{array}$ & $\begin{array}{l}\text { Students } \\
(40)\end{array}$ & $\begin{array}{l}\text { Mathematical } \\
\text { thinking } \\
\text { structure in } \\
\text { analytic } \\
\text { geometry }\end{array}$ & $\begin{array}{l}\mathrm{p}- \\
\text { value }<0.05\end{array}$ \\
\hline 10 & Khalil ( 2017)* & Geometry & $\begin{array}{l}\text { Analytic } \\
\text { geometry }\end{array}$ & $\begin{array}{l}\text { Students } \\
(40)\end{array}$ & $\begin{array}{l}\text { Problem- } \\
\text { solving ability }\end{array}$ & $\begin{array}{l}\mathrm{P}- \\
\text { value }=0.073 \\
>0.05\end{array}$ \\
\hline 11 & $\begin{array}{l}\text { Reis and } \\
\text { Ozdemir } \\
(2010)\end{array}$ & Geometry & $\begin{array}{l}\text { Analytic } \\
\text { geometry }\end{array}$ & $\begin{array}{l}\text { Students } \\
(204)\end{array}$ & $\begin{array}{l}\text { To describe the } \\
\text { parabola } \\
\text { equation }\end{array}$ & $\begin{array}{l}\text { t-test }=- \\
26,298 \\
\mathrm{p}=, 000 \\
<0.05\end{array}$ \\
\hline 12 & $\begin{array}{l}\text { Yildiz and } \\
\text { Baltaci (2016) }\end{array}$ & Geometry & $\begin{array}{l}\text { Analytic } \\
\text { geometry }\end{array}$ & - & $\begin{array}{l}\text { Cylindrical and } \\
\text { spherical } \\
\text { coordinates }\end{array}$ & - \\
\hline
\end{tabular}


African Journal of Educational Studies in Mathematics and Sciences Vol. 16, No. 1. 2020

\begin{tabular}{|c|c|c|c|c|c|c|}
\hline SN & Author & $\begin{array}{l}\text { Domain of } \\
\text { Mathematics }\end{array}$ & Topics & Sample & Variables & $\begin{array}{l}\text { Statistical } \\
\text { significance }\end{array}$ \\
\hline 13 & $\begin{array}{l}\text { Herceg and } \\
\text { Herceg }(2010\end{array}$ & Calculus & Integration & - & $\begin{array}{l}\text { Numerical } \\
\text { integration }\end{array}$ & - \\
\hline 14 & Aydos (2015) & Calculus & $\begin{array}{l}\text { Limit and } \\
\text { continuity }\end{array}$ & $\begin{array}{l}\text { Students } \\
\text { (34) }\end{array}$ & $\begin{array}{l}\text { Limit and } \\
\text { continuity }\end{array}$ & $\begin{array}{l}\text { A gain of } \\
1.33 \\
\text { between } \\
\text { groups }\end{array}$ \\
\hline 15 & Ocal (2017) & Calculus & Derivatives & $\begin{array}{l}\text { Students } \\
(55)\end{array}$ & $\begin{array}{l}\text { Application of } \\
\text { derivatives }\end{array}$ & $\mathrm{p}=.007<.05$ \\
\hline 16 & Ocal $(1017)^{*}$ & Calculus & Derivatives & $\begin{array}{l}\text { Students } \\
(55)\end{array}$ & $\begin{array}{l}\text { procedural } \\
\text { knowledge }\end{array}$ & $\mathrm{p}=.287>.05$ \\
\hline 17 & $\begin{array}{l}\text { Mushipe and } \\
\text { Ogbonnaya, } \\
\text { (2019) }\end{array}$ & Algebra & $\begin{array}{l}\text { Linear } \\
\text { functions }\end{array}$ & $\begin{array}{l}\text { Students } \\
(62)\end{array}$ & - & $\begin{array}{l}\text { Effect of } \\
0.53 \text { with } \\
\text { SD } \\
\text { difference is } \\
6.79\end{array}$ \\
\hline 18 & $\begin{array}{l}\text { Mudaly and } \\
\text { Fletcher (2019) }\end{array}$ & Algebra & $\begin{array}{l}\text { Linear } \\
\text { algebra }\end{array}$ & $\begin{array}{l}\text { Students } \\
(27)\end{array}$ & $\begin{array}{l}\text { Gradient and y- } \\
\text { intercept of a } \\
\text { straight line }\end{array}$ & - \\
\hline 19 & $\begin{array}{l}\text { Zengin et al. } \\
(2012)\end{array}$ & Trigonometry & - & $\begin{array}{l}\text { Students } \\
\text { (51) }\end{array}$ & - & - \\
\hline 20 & $\begin{array}{l}\text { Ibrahim and } \\
\text { Llyas (2016) }\end{array}$ & Trigonometry & $\begin{array}{l}\text { Trigonome } \\
\text {-tric } \\
\text { functions }\end{array}$ & $\begin{array}{l}\text { Students } \\
(36)\end{array}$ & $\begin{array}{l}\text { Periodicity of a } \\
\text { trigonometric } \\
\text { function }\end{array}$ & - \\
\hline
\end{tabular}

*Indicates where GeoGebra was found not effective

\section{Findings and Discussion}

\section{Effectiveness of GeoGebra in Geometry}

The reviewed literature showed twelve studies that were conducted on GeoGebra integration and its effectiveness in Geometry.

In a study conducted by Seloraji and Eu (2017) aiming at determining whether GeoGebra enhances Year One students in geometrical reflection, three groups of students were formed and taught the same content. One group of 24 Year One student was taught and learned with GeoGebra and all groups faced pre-posttest. Students' activity in the experimental group was to draw themselves buildings and then reflect on the buildings drawn. By the use of Analysis of Variance (ANOVA), statistical results showed that there is a significant statistical difference in mean scores, in favor of the group taught and learned with the use of GeoGebra, with $p<$ .05 level in scores for three ability groups $(\mathrm{F}(2,23)=15.070)$. It was concluded that GeoGebra improves students' achievements in Geometry. Likewise, Shadaan and Eu (2013) investigated the effectiveness of GeoGebra on students' understanding of learning circles, fifty-three Year 9 (Form 3) students were participants of the study. Students were put into two groups; experimental and control groups. Students in the experimental group were learning using videos. It was found that the use of GeoGebra in the experimental group performed higher than the control group. Besides, Masri et al. (2016) while examining the impact of GeoGebra on teaching and learning of Circles in Form Four Malaya students. Students were constructing 
GeoGebra Integration and Effectiveness in the Teaching and Learning of Mathematics in Secondary Schools: A Review of Literature

M. S. Uwurukundo, J. F. Maniraho \& M. Tusiime Rwibasira examples and drawings from the textbook by the use of GeoGebra software. The users were given instructions on how to learn mathematical concepts of the circle by exploring and investigating mathematical ideas. The fact of changing and visualizing images would have enabled students to master the concepts of the circle, however, by using one-way ANOVA with a one-sample t-test found no mean scores difference between the two groups.

Saha et al. (2010) were interested in investigating the effects of GeoGebra on Mathematics achievement with a focus on learning coordinate geometry. Fifty-three secondary school students participated in the study. A quasi-experimental study was employed, where students were divided into two groups: high visual-spatial ability students (HV) and low visual-spatial ability students (LV), and both groups were taught the same content. One group was subjected to teaching with GeoGebra while another was subjected to traditional teaching methods. Three types of special activities including cube construction, 3D special ability tasks, and mental rotation tasks were performed using GeoGebra. Independent samples t-test findings indicated that the LV students who learnt with GeoGebra-aided $(\mathrm{M}=64.07, \mathrm{SD}=21.569)$ got a significant performance compared to the HV students who learnt with traditional methods $(M=48.79$, $\mathrm{SD}=15.106) ; \mathrm{t}(51)=2.222, \mathrm{p}=.036<.05$. These findings confirmed that GeoGebra is effective in enhancing students in learning Coordinate Geometry.

Jelatu, Sariyasa, and Ardana (2018) were interested in investigating students' acquisition of spatial ability on the understanding of geometry concepts. Then, 60 students of Grade 8 were put into two groups and taught the same content. Students in the experimental group were assisted to understand the concepts of Geometry by using GeoGebra-aided Relating, Experiencing, Applying, Cooperating, and Transferring (REACT) strategy. With two-way ANOVA used to analyze data, it was found that there was a higher achievement for students who were taught with GeoGebra in understanding the concepts of geometry in general, compared to the other group that was taught with conventional methods (expository). However, no effect was found between GeoGebra-aided and students' spatial ability to understand geometric concepts. Besides, Reis and Ozdemir (2010) wanted to know about the effectiveness of GeoGebra on students' academic performance in learning the parabola in analytic geometry. Two hundred and four, Grade 12 were used in the study. A quasi-experimental was referred to and students were put into the experimental and control group. The teaching materials for the experimental group were prepared with the use of GeoGebra, whereby the content was made of various pieces of parabola sections questions and everyday life examples. After a post-test, with the use of an independent t-test, results showed that there was a significant statistical difference between the groups. Also, GeoGebra provided both teachers and students the visualization and dynamic interpretation of geometric shapes.

While wondering how GeoGebra can enhance preservice teachers to learn cylindrical and spherical coordinates by matching them with the context and environments using GeoGebra software to fill the gap between abstract mathematical concepts and real situation, Yildiz and Baltaci (2016) used instruments composed of worksheets and semi-structured interviews. Preservice teachers were expected to interpret each ordered pair corresponds to $\mathrm{R}^{2}$ and triplet pair $\mathrm{R}^{3}$ in a right cylinder with center 0 and the $\rho$-radius on a sphere. Preservice teachers were asked to determine the coordinates of a key, which was in a closet and a lamp, which was hung on a wall. Also, the preservice teachers were also asked to identify the location of an object which is on the cylindrical water glass. It was confirmed that preservice mathematics teachers are facilitated to acquire cylindrical and spherical coordinates. Furthermore, Singh (2018) investigated the role played by GeoGebra on students' geometry achievements, the quasiexperimental study was employed, and 23 students formed an experimental taught with 
GeoGebra-aided, while 22 students formed a control group. For the experimental group, the lesson materials were prepared using GeoGebra, and the content taught was about Euclidian Geometry, lines, angles, and triangle. After the data collected and analyzed from a post-test, the results showed that the experimental group outperformed in geometry compared to their counterpart in the control group. It was therefore drawn an implication that GeoGebra is effective in boosting effective instructions of geometry in secondary schools.

Khalil, Farooq, Çakiroglu, Khalil, and Khan (2018) wanted to make instructional exploration of analytic geometry and the effectiveness of GeoGebra. Then, the authors made two groups of Grade 11 students; low achievers and high achievers which have the same statistical background. A period of two weeks was used, where high achievers were subjected to traditional methods while low achievers were subjected to GeoGebra -aided instructions through drills and practices. Students were asked to learn analytic geometry with an applet and later asked to solve problems with the use of GeoGebra. Analyzing the treatment effect, the ttest was used by SPSS $t$ calculated $=2.6$ and $p$-value $=0.012<0.05$. It was found that the experimental group made of low achievers performed well, in comparison with the control group. This study was supported by Khalil (2017) who wanted to explore the effectiveness of GeoGebra in enhancing students' mathematical thinking structure in analytic geometry. To carry out the study, forty students (Grade-12) were used and put into two groups; experimental and control group. The experimental group students were engaged to learn the analytic geometry concept through applets and further they were also assigned to solve the problems with the help of GeoGebra. With the use of a t-test, P-value $=0.073>0.05$, the statistical findings indicated that the experimental group got higher performance in analytical thinking, generalization, abstract thinking, representation, and logical thinking as compared to the control group. However, no significant difference was observed about problem-solving ability between the two groups.

\section{Effectiveness of GeoGebra in Calculus}

The reviewed literature showed that four studies were conducted on GeoGebra integration and effectiveness in Calculus.

Aydos (2015) studied students' achievement in limit and continuity. A quasi-experimental study was then employed. The sample was made of 34 students. Hence, two groups were formed, whereby one group was taught with GeoGebra, while another was taught with traditional methods. The students' activity was about changing the value of $\mathrm{x}$ and asked to estimate where the function is converging to. Students could also observe the demonstrations from the teacher as explaining the convergence of the function. Later, students could discuss the concept of infinity with the GeoGebra applet by interpreting the graphs. For instance, students discovered that as $\mathrm{x}$ approached 3, the value of the function was getting bigger and bigger. After that, two groups faced pre-posttest, the data analysis with independent t-test showed that there are again scores in the experimental group with 1.33 higher than the control group. GeoGebra was therefore viewed to be an effective tool in teaching calculus especially limit and continuity for students. Likewise, Ocal (2017) wanted to find out if the integration of GeoGebra in lesson delivery affects students' achievement in learning the application of derivative. Two groups of students were formed and both faced pre-posttest. Students in experimental groups were observing demonstrations from the instructor while solving questions and doing activities with the use of GeoGebra. For instance, the teacher explained the derivative meaning where students were shown that the instant change of the value of $\mathrm{x}$ influences the change in the slope, and the teacher did this by dragging the property of GeoGebra. After the post-test, with an independent samples t-test, the results from analyzed data showed that an experimental group scored higher $(\mathrm{M}=7.26, \mathrm{SD}=2.503)$ than the control 
GeoGebra Integration and Effectiveness in the Teaching and Learning of Mathematics in Secondary Schools: A Review of Literature

M. S. Uwurukundo, J. F. Maniraho \& M. Tusiime Rwibasira group $(\mathrm{M}=5.33, \mathrm{SD}=2.590)$; $\mathrm{t}(53)=2.786, \mathrm{p}=.007<.05)$. Therefore, the findings showed that instruction with GeoGebra has a positive impact on students' performance as far as conceptual knowledge is concerned. However, with $\mathrm{p}=.287>.05$, the author found that there is no differential effect of GeoGebra regarding procedural knowledge between both experimental and control groups.

While researching on students' attainment in numerical integration, Herceg and Herceg (2010) employed an experimental study whereby two groups of students were formed. An experimental group was taught with GeoGebra software, and a control group was taught with conventional methods. Students were asked to perform the Riemann sum calculations with random partitioning of the integration interval, which was repeated several times with the support of graphical representations. Left, right, and middle Riemann sum was also explored. Various integrands were demonstrated with the different domains of integration. Trapeze rule and Simpson's rules were further demonstrated. It was noticed that Simpson's rules were very useful for the class since they could not be easily explained without the use of GeoGebra software. The study's results showed that the experimental group outperformed in numerical integration than its counterpart group.

\section{Effectiveness of GeoGebra in Algebra}

The reviewed literature showed two studies on GeoGebra integration and effectiveness.

Based on reports that teachers struggle with teaching functions, and learners struggling with learning functions, Mushipe and Ogbonnaya, (2019) conducted a study on Grade 9 students. Sixty-two students were involved in the study. The study sought to find out how GeoGebra integration affects teaching and learning of linear functions in the Grade 9 level of learning. Two groups, experimental and control groups of students were formed. Students in the experimental group learned linear functions with the use of GeoGebra. Students were free to explore linear functions, individually or in pairs, which enabled them to understand more linear functions. Students could also check the correctness of their results in the absence of the instructor. Students could draw and analyze the graphs. After a post-test data were analyzed by using a t-test, the finding revealed that the experimental group $(\mathrm{M}=51.76$; SD 17.95) that learned with the use of GeoGebra outperformed its counterpart group ( $M=20.00$, SD 11.16) with the large effect measured at 0.53 . The authors suggested that the use of GeoGebra in teaching and learning mathematics enhances students' performance in learning linear functions. Besides, Mudaly and Fletcher (2019) were interested to investigate if GeoGebra can supports the teaching of straight line properties in algebra specifically in learning gradient and $y$-intercept. Then, students learned properties of straight line graphs known as gradient and yintercept by using the applet. The qualitative data were afterward collected to understand how effective the GeoGebra app is in helping students to discover properties of a straight line. The results showed that GeoGebra helped learners to discover the properties of a straight line. It was also noticed that learners had a positive attitude towards an applet and enjoyed interacting with the software.

\section{Effectiveness of GeoGebra in Trigonometry}

The reviewed literature showed two discussed studies in Trigonometry.

In the research carried out by Yilmaz et al. (2012) determining the effect brought about by GeoGebra software to enhance students' performance in Trigonometry, 51 students were used in the study. A quasi-experimental study was conducted. Two groups were used, whereby one group taught with GeoGebra software, and a control group was taught with constructivist 
instructions. GeoGebra related activities were prepared to make the subject more dynamic, concrete, and visual. All prepared GeoGebra activities were shared with learners in visual and dynamic manners. Later, examples and drawings from the textbooks were performed by students using GeoGebra during the instruction process. Comparing the results between pre and posttest using independent t-test, the results showed a statistical significant difference between the control group $(\bar{X}=54.09, \mathrm{SD}=9.83)$ and the experimental group $(\bar{X}=72.39, \mathrm{SD}=$ $12,51 ; \mathrm{t}(51)=5.43, \mathrm{p}=.000<.05)$. The finding showed that learning trigonometry with GeoGebra use is significantly better than learning it through constructivism instruction. Besides, Ibrahim and Llyas (2016) conducted a study on the effect of GeoGebra in teaching the concepts of periodicity in trigonometric functions. A quasi-experimental study was conducted, 36 tenth grade high school students participated in the study. Students in the experimental group learned with GeoGebra-aided instructions where students had to follow the teacher demonstrating and drawing graphs. After 15 days of instructions, both experimental and control groups students were given five questions which were analyzed descriptively. Referring to the findings of the study, GeoGebra-aided instruction in mathematics education was found more effective than the traditional way of teaching mathematics.

The reviewed literature showed that 16 out of 20 studies or $(80 \%)$ conducted, the results showed that GeoGebra integration is effective in enhancing students' performance in terms of analytical thinking, abstract thinking, representations, graphs drawing, and their interpretations. Only four out of 20 studies or $(20 \%)$ showed GeoGebra integration was not effective in teaching and learning mathematics since the results showed that there is no difference between groups in their performance after a posttest. The reviewed literature showed that GeoGebra played a significant contribution in enhancing students' understanding of mathematical concepts and performance in mathematics (Ocal, 2017) and that GeoGebra enhanced students' interest to learn (Kim \& Md-ali, 2017; Y1lmaz, 2017). This may be explained in a way that GeoGebra was used to visualize and explore mathematical ideas, structures, and relations (Hanč et al., 2011). In order to investigate the relevance of employing GeoGebra in teaching and learning mathematics, many researchers have used experimental studies, where students were given a pre-posttest ( eg. Saha et al. 2010; Seloraji and Eu, 2017; Khalil, Farooq, Çakiroglu, Khalil, and Khan, 2018), while few researchers have used interviews (eg. Yildiz \& Baltaci, 2016; Mudaly \& Fletcher, 2019) to investigate students' views and attitudes towards GeoGebra. Some teachers taught using GeoGebra while demonstrating and explaining mathematical concepts (Ibrahim \& Llyas, 2016; Ocal, 2017), however, other teachers opted to give some activities to students ( Herceg \& Herceg, 2010; Aydos, 2015) where students interacted with the software. Students were also expected to answer to some problems with the use of GeoGebra and some of these problems were in their textbooks.

As shown in Table 1, the majority of studies conducted on GeoGebra effectiveness were found in Geometry. The results showed that nine out of twelve studies considered showed that GeoGebra use is effective while only three were reported to be not effective in Geometry. In the domain of Calculus, four studies were conducted where the reviewed three studies showed GeoGebra's effectiveness in learning Calculus while one study showed non-effectiveness. When we looked at the domain of Trigonometry, for two reviewed studies, the findings showed that GeoGebra enhanced learning, while in the domain of Algebra, also two studies reviewed showed the effectiveness in learning Mathematics.

\section{Conclusion and policy implications}

This review of the literature was done to investigate how GeoGebra was integrated and why it was reported to be effective in enhancing students' performance in Mathematics. Though the reviewed studies are not exhaustive, they provide a clear picture of how GeoGebra was 
GeoGebra Integration and Effectiveness in the Teaching and Learning of Mathematics in Secondary Schools: A Review of Literature

M. S. Uwurukundo, J. F. Maniraho \& M. Tusiime Rwibasira integrated and what has been its contribution to enhancing students' mathematical concepts understanding. In addition, the literature showed that students have the potentialities of exploring independently the GeoGebra applet and get a sense of the concept with minimum support from the teacher. It was also seen that students got interested while interacting with GeoGebra software. Although the reviewed studies showed that GeoGebra is more effective in teaching and learning in Geometry, however, there is a need to know why the most reviewed studies were conducted in Geometry, while few studies were conducted in other domains as it is shown by the reviewed literature. With the ICT integration in education, especially in Science, Technology, Engineering, and Mathematics (STEM) subjects that continues to be embraced by many countries, more studies need to be conducted investigating to what extent GeoGebra integration added values in learning mathematics. Since ICT integration in education cannot replace a teacher, hence, teachers need to be equipped with both content knowledge, skills of applying effectively those technologies, and pedagogy, to facilitate teaching and learning processes towards students' attainment.

\section{References}

Adegoke, I. A. (2016). GeoGebra: The Third Millenium Package for Mathematics Instruction in Nigeria. Anale. Computer Science, 14(1), 35-43. http://analeinformatica.tibiscus.ro/download/lucrari/14-1-05-Akanmu.pdf

Akkaya, A., Tatar, E., \& Kağizmanli, T. B. (2011). Using dynamic software in the teaching of the symmetry in analytic geometry: The case of GeoGebra. Procedia - Social and Behavioral Sciences, 15, 2540-2544. https://doi.org/10.1016/j.sbspro.2011.04.141

Andresen, M., \& Misfeldt, M. (2010). Essentials of Teacher Training Sessions with GeoGebra. International Journal for Technology in Mathematics Education, 17(4), 169-176. http://www.eric.ed.gov/ERICWebPortal/detail?accno=EJ913350

Aydos, M. (2015). The Impact of teaching Mathematics with GeoGebra on the conceptual Understanding of Limits and Continuity: the case of Turkish gifted and talented Students [Unpublished Master thesis.Ihsan Dogrammaci Bilkent University]. https://doi.org/10.1377/hlthaff.2013.0625

Azizul, S. M. J., \& Din, R. (2016). Teaching and Learning Geometry Using Geogebra. Journal of Personalized Learning, 2(1), 40-51.

Baltachi, S., \& Yildiz, A. (2015). GeoGebra 3D from the perspectives of elementary preservice mathematics teachers who are familiar with a number of software programs. Cyprio Journal of Education, 10(1), 12-17.

Bulut, M., Akçakın, H. Ü., Kaya, G., \& Akçakın, V. (2016). The effects of GeoGebra on thirdgrade primary students' academic achievement of fractions. Mathematics Education, 11(2), 327-335. https://doi.org/10.12973/iser.2016.2109a

Chimuka, A. (2017). The Effect of Integration of GeoGebra Software in the Teaching of Circle Geometry on Grade 11 Students (Issue May) [Unpublished Master thesis. University of South

Africa]. https://pdfs.semanticscholar.org/4601/0aad0e995cee4eb0d0be47e8a0e475aa7e13.pdf

Dikovic, L. (2009). Implementing Dynamic Mathematics Resources with GeoGebra at the College Level. 4(3), 51-54. https://doi.org/10.3991/ijet.v4i3.784

Doruk, B. K., Aktümen, M., \& Aytekin, C. (2013). Pre-service elementary mathematics teachers'opinions about using GeoGebra in mathematics education with reference to 
African Journal of Educational Studies in Mathematics and Sciences Vol. 16, No. 1. 2020

“teaching practices." Teaching Mathematics and Its Applications, 32(3), 140-157. https://doi.org/10.1093/teamat/hrt009

Escuder, A., \& Furner, J. M. (2011). The Impact of GeoGebra in Math Teacher's Professional Development. International Conference on Technologies in Collegiate Mathematics, $76-84$.

Haciomeroglu, E. S., Bu, L., Schoen, R. C., \& Hohenwarter, M. (2009). Learning to Develop Mathematics Lessons with GeoGebra. MSOR Connections, 9(2), 24-26. https://doi.org/10.11120/msor.2009.09020024

Hanč, J., Lukáč, S., Sekerák, J., \& Šveda, D. (2011). Geogebra - A complex digital tool for highly effective math and science teaching. ICETA 2011 - 9th IEEE International Conference on Emerging eLearning Technologies and Applications, Proceedings, 131136. https://doi.org/10.1109/ICETA.2011.6112601

Herceg, Đ., \& Herceg, D. (2010). Numerical Integration with GeoGebra in High School. International Journal for Technology in Mathematics Education, 17(4), 205-210.

Ibrahim, K., \& llyas, Y. (2016). Teaching a concept with GeoGebra: Periodicity of trigonometric functions*. Educational Research and Reviews, 11(8), 573-581. https://doi.org/10.5897/err2016.2701

Jelatu, S., Sariyasa, \& Made Ardana, I. (2018). Effect of GeoGebra-aided REACT strategy on an understanding of geometry concepts. International Journal of Instruction, 11(4), 325-336. https://doi.org/10.12973/iji.2018.11421a

Kamariah, A. B., Ahmad Fauzi, M. A., \& Rohani, A. T. (2010). Exploring the effectiveness of using GeoGebra and e-transformation in teaching and learning Mathematics. Advance Educational Technologies. https://www.researchgate.net/publication/228986613

Khalil, M. (2017). Exploration of mathematical thinking and its development through GeoGebra. Journal of Educational Research, 20(1), 83-99.

Khalil, M., Farooq, R. A., Çakiroglu, E., Khalil, U., \& Khan, D. M. (2018). The development of mathematical achievement in the analytic geometry of grade-12 students through GeoGebra activities. Eurasia Journal of Mathematics, Science and Technology Education, 14(4), 1453-1463. https://doi.org/10.29333/ejmste/83681

Kim, K. M., \& Md-ali, R. (2017). GeoGebra: Towards Realizing 21 st Century Learning in Mathematics Education. Malaysian Journal of Learning and Instruction. https://pdfs.semanticscholar.org/9425/ea513936217d67d6f258adc049360cce588e.pdf ?

Lavrakas, P. J. (2008). Encyclopedia of survey research methods (Vols. 1-0). Thousand Oaks, CA: Sage Publications, Inc. https://methods.sagepub.com/reference/encyclopedia-ofsurvey-research-methods/n91.xml

Lu, Y. W. A. (2009). Linking Geometry and Algebra: English and Taiwanese Upper Secondary Teachers' Approaches to the use of GeoGebra. Proceedings of the British Society for Research into Learning Mathematics, 29(1), 61-66. http://www.bsrlm.org.uk/IPs/ip291/BSRLM-IP-29-1-11.pdf

Mainali, B., \& Key, M. (2012). Using Dynamic Geometry Software GeoGebra in Developing Countries: A Case Study of Impressions of Mathematics Teachers in Nepal. http://www.cimt.plymouth.ac.uk/Journal/mainali.pdf

Masri, R., Hiong, T. S., Tajudin, M., \& Zamzamin, Z. Z. (2016). The effects of using GeoGebra 
GeoGebra Integration and Effectiveness in the Teaching and Learning of Mathematics in Secondary Schools: A Review of Literature

M. S. Uwurukundo, J. F. Maniraho \& M. Tusiime Rwibasira teaching strategy in Malaysian secondary schools: A case study from Sibu, Sarawak. Geografia - Malaysian Journal of Society and Space, 12(7), 13-25.

Mudaly, V., \& Fletcher, T. (2019). The effectiveness of GeoGebra when teaching linear functions using the IPad. Problems of Education in the 21st Century, 77(1), 55-81. https://doi.org/10.33225/PEC/19.77.55

Mushipe, M., \& Ogbonnaya, U. I. (2019). Geogebra and Grade 9 learners' achievement in linear functions. International Journal of Emerging Technologies in Learning, 14(8), 206-219. https://doi.org/10.3991/ijet.v14i08.9581

Njiku, J., Mutarutinya, V., \& Maniraho, J. F. (2020). Developing technological pedagogical content knowledge survey items: A review of the literature. Journal of Digital Learning in Teacher Education. https://doi.org/10.1080/21532974.2020.1724840

Ocal, M. F. (2017). The Effect of Geogebra on Students' Conceptual and Procedural Knowledge: The Case of Applications of Derivative. Higher Education Studies, 7(2), 67-78. https://doi.org/10.5539/hes.v7n2p67

Reis, Z. A., \& Ozdemir, S. (2010). Using Geogebra as an information technology tool: Parabola teaching. Procedia - Social and Behavioral Sciences, 9, 565-572. https://doi.org/10.1016/j.sbspro.2010.12.198

Saha, R. A., Ayub, A. F. M., \& Tarmizi, R. A. (2010). The effects of GeoGebra on mathematics achievement: Enlightening Coordinate Geometry learning. Procedia - Social and Behavioral Sciences, 8, 686-693. https://doi.org/10.1016/j.sbspro.2010.12.095

Saralar, İ., \& Ainsworth, S. (2017). An exploration of middle school mathematics teachers' beliefs and goals regarding GeoGebra: Four cases from the Turkish Republic. The European Conference on Educational Research: Reforming Education and the Imperative of Constant Change: Ambivalent Roles of Policy and Educational Research. University College Copenhagen, Copenhagen, Denmark: EERA ECER.

Seloraji, P., \& Eu, L. K. (2017). Students' Performance in Geometrical Reflection using Geogebra. Malaysia Online Journal of Educational Technology, 5(1), 65-77.

Shadaan, P., \& Eu, L. K. (2013). Effectiveness of Using GeoGebra on Students' Understanding in Learning Circles. Malaysia Online Journal of Educational Technology, 1(4), 1-11.

Singh, L. K. (2018). Impact of Using Geogebra Software on Students' Achievement in Geometry: A Study at Secondary Level. Asian Resonance, 7(5), 133-137.

Verhoef, N. C., Coenders, F., Pieters, J. M., van Smaalen, D., \& Tall, D. O. (2015). Professional development through lesson study: teaching the derivative using GeoGebra. Professional Development in Education, 41(1), 109-126. https://doi.org/10.1080/19415257.2014.886285

Wassie, Y. A., \& Zergaw, G. A. (2019). Some of the potential affordances, challenges, and limitations of using GeoGebra in mathematics education. Eurasia Journal of Mathematics, Science and Technology Education, 15(8), 1-11. https://doi.org/10.29333/ejmste/108436

Yildiz, A., \& Baltaci, S. (2016). Reflections from the Analytic Geometry Courses Based on Contextual Teaching and Learning through GeoGebra Software. The Online Journal of New Horizons in Education, 6(4), 155-166. 
African Journal of Educational Studies in Mathematics and Sciences Vol. 16, No. 1. 2020

Yilmaz, Z., Furkan, H., \& Kutluca, T. (2012). The effect of dynamic mathematics software GeoGebra on student achievement in the teaching of trigonometry. Procedia - Social and Behavioral Sciences, 31, 183-187. https://doi.org/10.1016/j.sbspro.2011.12.038

Y1lmaz, Z. (2017). The effects of GeoGebra software on pre-service mathematics teachers' attitudes and views toward proof and proving. International Journal of Mathematical Education in Science and Technology, 48(7), 1002-1022. https://doi.org/10.1080/0020739X.2017.1298855

Žilinskienè, I., \& Demirbilek, M. (2015). Use of GeoGebra in Primary Math Education in Lithuania: An Exploratory Study from Teachers 'Perspective. 14(1), 127-142. 